\title{
Sistem Informasi Pelatihan pada Kantor Unit Pelaksana Teknis Latihan Kerja Industri (UPT LKI) Provinsi Kalimantan Barat
}

\author{
Arief Ramadhayansyah Yusmita ${ }^{\mathrm{a} 1}$, Hengky Anra ${ }^{\mathrm{a} 2}$, Haried Novriando ${ }^{\mathrm{a} 3}$ \\ aProgram Studi Informatika Universitas Tanjungpura \\ Jl. Prof. Dr. Hadari Nawawi Pontianak 78124 \\ ${ }^{1}$ ariefry008@gmail.com \\ ${ }^{2}$ hengkyanraeinformatika.untan.ac.id \\ ${ }^{3}$ hariedeinformatika.untan.ac.id
}

\begin{abstract}
Abstrak
Kompetensi adalah modal utama bagi calon tenaga kerja baik itu untuk mandiri maupun untuk bekerja dengan orang lain. Untuk meningkatkan kualitas kompetensi sumber daya manusia harus melalui suatu proses pendidikan dan pelatihan di bidangnya masing-masing. UPT LKI atau "Unit Pelaksana Teknis Latihan Kerja Industri" Provinsi Kalimantan Barat merupakan pusat pelatihan vokasi yang menyelenggarakan pelatihan dan uji keterampilan tenaga kerja dalam berbagai bidang keterampilan kerja industri. Permasalahan utama yang dihadapi oleh UPT LKI adalah sistem pendaftaran dan informasi yang mengharuskan calon siswa untuk datang langsung ke lokasi. Untuk itu diperlukan suatu sistem yang dapat menampung pendaftaran dan informasi yang dapat diakses oleh masyarakat. Penelitian ini bertujuan untuk merancang sistem penerimaan siswa yang dapat membantu para pelamar dalam proses pendaftaran dan penerimaan informasi terkait. Penelitian ini menggunakan metode waterfall untuk merancang dan mengimplementasikan aplikasi. Adapun pengujian yang digunakan adalah user acceptance test (UAT) dan blackbox. Hasil pengujian blackbox menunjukan bahwa fungsi fitur yang ada dalam aplikasi sudah berjalan dengan baik. Berdasarkan pengujian UAT, aplikasi ini mendapatkan rata rata persentasi $82,85 \%$ dan masuk dalam kategori sangat baik. Berdasarkan penelitian yang telah dilakukan, aplikasi yang telah dibangun dapat dimanfaatkan dan diterapkan pada UPT LKI.
\end{abstract}

Kata kunci: UPT LKI, Sistem Informasi, Blackbox, UAT

\section{Training Information System at the Office of the Technical Implementation Unit of Industrial Work Training (UPT IFI) of West Borneo Province}

\begin{abstract}
Competence is the main capital for prospective workers both to be independent and to work with others. To improve the quality of the human resource competencies must go through a process of education and training in their respective fields. The LKI UPT or the "Industrial Work Training Technical Implementation Unit" of West Kalimantan Province is a vocational training center that organizes training and testing of labor skills in various fields of industrial work skills. The main problem faced by the IFI UPT is the registration and information system, which requires prospective students to come directly to the location. For this reason, a system that can accommodate registration and information that can be accessed by the public is needed. This study aims to design a student admission system that can help applicants in the process of registering and receiving related information. This research uses the waterfall method to design and implement applications. The test used is the user acceptance test (UAT) and BlackBox. Blackbox test results show that the features in the app are running well. Based on UAT testing, this application gets an average percentage of $82.85 \%$ and falls into the first category. Based on research has been done, claims that have been built can be utilized and applied to the IFI UPT.
\end{abstract}

Keywords: UPT LKI, Information Systems , Blackbox, UAT

\section{PENDAHULUAN}

Manusia sebagai perencana, pelaksana, pengendali dan evaluasi pembangunan serta manusia mempunyai peran yang sangat menentukan dalam keberhasilan pembangunan, hal tersebut dapat dicapai apabila manusia memiliki kompetensi. Kompetensi adalah modal utama bagi calon tenaga kerja baik itu untuk mandiri maupun untuk bekerja dengan orang lain. UPT LKI atau "Unit Pelaksana Teknis Latihan Kerja Industri Provinsi Kalimantan Barat" merupakan pusat pelatihan (Vocation 
Training Centre) Kalimantan Barat yang terletak di jalan Abdurrahman Saleh Pontianak, dengan tugas pokok menyelenggarakan pelatihan dan uji keterampilan tenaga kerja dalam berbagai bidang keterampilan kerja industry. Adapun tata cara untuk masyarakat yang ingin meningkatkan keterampilan mesti mengikuti alur pendaftaran yang mengharuskan masyarakat selalu datang untuk mencari informasi langsung ke kantor UPT LKI. Setelah mengikuti pelatihan di kantor UPT LKI maka siswa akan mendapatkan sertifikat berdasarkan kemampuan yang telah dikuasainya. Keaslian sertifikat berdampak pada peningkatan kepercayaan suatu perusahaan atau tempat kerja terhadap calon karyawannya oleh karena itu verifikasi diperlukan agar keaslian sertfikat diketahui kebenarannya.

\section{TINJAUAN PUSTAKA}

\section{A. Pengertian Sistem}

Sistem adalah suatu integrasi bagian sistem informasi yang semuanya bekerja menuju suatu tujuan. Sistem terdiri dari tiga elemen utama yaitu input, pengolahan data dan output. Sistem juga dapat dibagi menjadi beberapa sistem ataupun sub sistem, yang masing-masing bagian mempunyai bagian umum seperti perangkat lunak, perangkat keras, manusia, basis data, prosedur dan dokumentasi [1].

Pengertian dan definisi sistem pada umumnya adalah suatu kesatuan yang terdiri atas komponen atau elemen yang saling berinteraksi, saling terkait, atau saling bergantung membentuk keseluruhan yang kompleks. Sistem adalah kumpulan elemen yang saling terhubung atau berinteraksi membentuk suatu kesatuan atau sekumpulan komponen yang saling terhubung dan bekerja sama untuk mencapai sasaran dengan menerima input dan menghasilkan output dalam sebuah proses transformasi yang terorganisir [2].

\section{B. Pengertian Informasi}

Informasi dapat didefenisikan sebagai hasil dari pengolahan data dalam suatu bentuk yang lebih berguna dan lebih berarti bagi penerimanya yang menggambarkan suatu kejadian-kejadian (event) yang nyata (fact) yang digunakan untuk pengambilan keputusan [3].

Pengertian Informasi pada umumnya adalah data yang telah diproses menjadi bentuk yang memiliki arti bagi penerima dan dapat berupa fakta, suatu nilai yang bermanfaat. Ada suatu proses transformasi data menjadi suatu informasi yaitu input- proses -output.

Informasi adalah data yang diolah menjadi suatu bentuk yang lebih berguna dan lebih berarti bagi penerimanya yang menggambarkan suatu kejadian-kejadian (event) nyata yang digunakan untuk pengambilan suatu keputusan.

\section{Pengertian Sistem Informasi}

Sistem informasi terdiri dari semua komponen yang bekerja sama untuk mengolah data dan prosedur informasi. Komponen sistem informasi terdiri dari unsur-unsur seperti masukan (input), pengolahan (processing), keluaran (output) serta umpan balik (feedback) [4].

Pengertian sistem informasi pada umumnya adalah suatu sistem terintegrasi yang mampu menyediakan informasi yang bermanfaat bagi penggunanya, untuk menyediakan informasi untuk mendukung operasi, manajemen dalam suatu organisasi. Sistem ini memanfaatkan perangkat keras dan perangkat lunak komputer, prosedur manual, model manajemen dan basis data.

Sistem informasi adalah suatu sistem didalam suatu organisasi yang mempertemukan kebutuhan pengolahan transaksi harian, mendukung operasi, bersifat manajerial dan kegiatan strategi dari suatu organisasi dan menyediakan pihak luar tertentu dengan laporan-laporan yang diperlukan.

\section{Waterfall}

Model waterfall adalah model pengembangan perangkat lunak yang paling sering digunakan. Model pengembangan ini bersifat linear dari tahap awal pengembangan system yaitu tahap perencanaan sampai tahap akhir pengembangan system yaitu tahap pemeliharaan. Tahapan berikutnya tidak akan dilaksanakan sebelum tahapan sebelumnya selesai dilaksanakan dan tidak bisa kembali atau mengulang ke tahap sebelumnya [5].

Waterfall merupakan salah satu proses permodel perangkat lunak yang mengambil kegiatan proses dasar seperti spesifikasi, pengembangan, validasi dan evolusi dengan mempresentasikannya sebagai fase-fase proses yang berbeda seperti analisis dan definisi persyaratan, perancangan perangkat lunak, implementasi dan pengujian unit, integrasi dan pengujian sistem, operasi dan pemeliharaan [6].

\section{E. Business Process Modelling and Notation}

Dalam menjalankan proses bisnisnya, setiap perusahaan menerapkan prosedur yang bervariasi. Ada kalanya prosedur yang digunakan antara satu perusahaan dan perusahaan yang lain sama, namun juga tidak jarang setiap perusahaan menggunakan prosedur yang berbeda [7].

Business Process Modeling Notation (BPMN) menggambarkan suatu bisnis proses diagram yang mana didasarkan kepada teknik diagram alur, dirangkai untuk membuat model-model grafis dari operasi-operasi bisnis dimana terdapat aktivitas aktivitas dan kontrol-kontrol alur yang mendefinisikan urutan kerja [8].

\section{F. Data Flow Diagram (DFD)}

Data Flow Diagram adalah sebuah tool yang digunakan untuk membuat diagram dengan menggunakan beberapa simbol sederhana untuk mengilustrasikan aliran data antara entitas external, aktivitas proses, dan elemen penyimpanan data [9].

Data flow diagram merupakan model dari sistem untuk menggambarkan pembagian sistem ke modul yang lebih kecil. Tingkatan DFD dimulai dari diagram konteks yang menjelaskan secara umum suatu sistem atau batasan sistem aplikasi yang akan dikembangkan [10] Salah satu 
keuntungan menggunakan diagram alir data adalah memudahkan pemakai atau user yang kurang menguasai bidang komputer untuk mengerti sistem yang akan dikerjakan

\section{G. Entity Relationship Diagram (ERD)}

ERD adalah teknik pemodelan data yang dapat membantu mendefinisikan suatu proses bisnis dan dapat juga digunakan untuk mengetahui hubungan antar database [11].

\section{H. Blackbox}

Metode pengujian black box dipilih karena metode pengujian tersebut tidak memperhatikan struktur logika internal (coding) dalam perangkat lunak. Pengujian Black Box yakni pengujian yang berfokus pada persyaratan fungsional sistem yang telah dibuat [12]. Pada pengujian ini didasarkan pada detail aplikasi seperti tampilan aplikasi, fungsi-fungsi yang ada pada aplikasi, dan kesesuaian alur fungsi dengan proses yang diinginkan oleh pengguna. Pengujian ini tidak melihat dan tidak menguji souce code program.

Beberapa cara untuk memilih data pengujian untuk metode black box adalah sebagai berikut :

1) Easy values: yaitu data yang mudah diperiksa.

2) Typical realistic value; yaitu mencoba program dengan data pengujian untuk melihat bagaimana program menggunakannya. Data ini harus cukup sederhana sehingga hasilnya dapat dihitung secara manual.

3) Extreme values; banyak program error pada suatu batas range dari aplikasi.

4) Illegal values; yaitu suatu data / nilai yang tidak diperbolehkan maupun data yang tidak berguna.

Meskipun dirancang untuk mengungkap kesalahan, pengujian black box digunakan untuk memperlihatkan bahwa fungsi-fungsi perangkat lunak dapat beroperasi, bahwa input diterima dengan baik dan output dihasilkan dengan tepat, dan integritas informasi eksternal (seperti file data) dipelihara. Dalam pengujian black box terdapat beberapa sifat black box testing yaitu :

1) Robustness testing: (menguji kekuatan sistem yang ada) untuk menjamin sistem dengan memasukan data-data yang abnormal.

2) Performance testing: (menguji kinerja sistem yang ada) menguji software bagian dari sistem/orientasi kepada hardware.

3) Endurance testing: (menguji daya tahan sistem) menguji daya tahan terhadap software apakah sistem tersebut dapat bertahan dari gangguan- gangguan yang mengganggu.

4) Behavior testing: (menguji prilaku sistem apakah sudah sesuai dengan permintaan) menguji tingkah laku sistem berdasarkan polanya "didesain sebagai mana mulanya".

\section{User Acceptance Test (UAT)}

UAT (User Acceptance Test) adalah suatu proses pengujian yang dilakukan oleh pengguna dengan hasil output sebuah dokumen hasil uji yang dapat dijadikan bukti bahwa software sudah diterima dan sudah memenuhi kebutuhan yang diminta. UAT yang di gunakan pada penelitian ini dengan menggunakan kuesioner. Selama UAT, Pengguna yang sebenarnya menguji aplikasi untuk memastikan aplikasi dapat menangani tugas-tugas yang diperlukan dalam skenario dunia nyata, sesuai dengan spesifikasi [13].

Kuesioner adalah teknik pengumpulan data dengan menyerahkan atau mengirimkan daftar pertanyaan untuk diisi oleh responden [14]. Dalam penelitian survey pemakaian kuesioner merupakan hal penting untuk mengumpulkan data. Sebuah kuesioner yang baik adalah sebuah kuesioner yang mengandung pertanyaan yang baik pula, dalam arti sedemikian sehingga tidak menimbulkan arti yang lain pada diri responden. Pertanyaan-pertayaan pada kuesioner harus jelas dan mudah dimengerti sehingga mengurangi tingkat kesalahan interpretasi responden dalam pengisian kuesioner.

Teknik User Acceptance Test merupakan pengujian terakhir sebelum sistem dipakai oleh user yang melibatkan pengujian dengan data pengguna sistem. User Acceptance Test adalah uji terima perangkat lunak yang dilakukan di tempat pengguna oleh user perangkat lunak tersebut. Tujuan pengujian ini adalah untuk menguji apakah sistem sudah sesuai dengan apa yang tertuang dalam spesifikasi fungsional sistem (validation).Perhitungan dilakukan menggunakan skala likert. Skala likert merupakan suatu skala penilaian yang menyajikan pilihan skala dengan nilai pada setiap skala untuk mengukur tingkat persetujuan terhadap sesuatu [15]. Skala Likert digunakan untuk mengukur sikap, pendapat, dan persepsi seseorang atau sekelompok tentang kejadian atau gejala sosial dimana setiap pertanyaan memiliki bobot nilai. Adapun bobot jawaban yang diberikan adalah sangat baik (5), baik (4), cukup baik (3), kurang baik (2), tidak baik (1). Perhitungan dilakukan dengan rumus berikut:

$$
L=\frac{(\mathrm{SB} \times 5)+(\mathrm{B} \times 4)+(\mathrm{CB} \times 3)+(\mathrm{KB} \times 2)+(\mathrm{TB} \times 1)}{\mathrm{NB}} \times 100
$$

\section{J. Analisa Kebutuhan}

Selanjutnya dilakukan analisis sistem yang akan dikembangkan yaitu berupa sistem informasi berbasis web berkaitan dengan manajemen pelatihan:

- Masyarakat yang dapat mendaftarkan diri sebagai calon siswa.

- Proses verifikasi calon siswa dilakukan admin UPT LKI.

- Proses pengecekan penerimaan yang dilakukan calon siswa.

- Proses manajemen jadwal dan kejuruan yang dilakukan admin

- Proses manajemen galeri yang dilakukan admin

- Proses manajemen Alumni

- Proses pemberian nilai oleh instruktur 


\section{K. Rancang Aplikasi}

1. Arsitektur Aplikasi

Desain arsitektur sistem merupakan sekumpulan dari model-model terhubung yang menggambarkan sifat dasar dari sebuah sistem. Banyak model arsitektur sistem yang ada, dapat menggambarkan bagian berbeda dan aspek atau pandangan yang berbeda dari suatu sistem. Setiap komponen terdiri dari blok pembangun sistem yang dapat dibangun dengan cara menyatukan sekumpulan komponen berdasarkan aturan tertentu. Arsitektur aplikasi dapat dilihat pada Gambar 1.

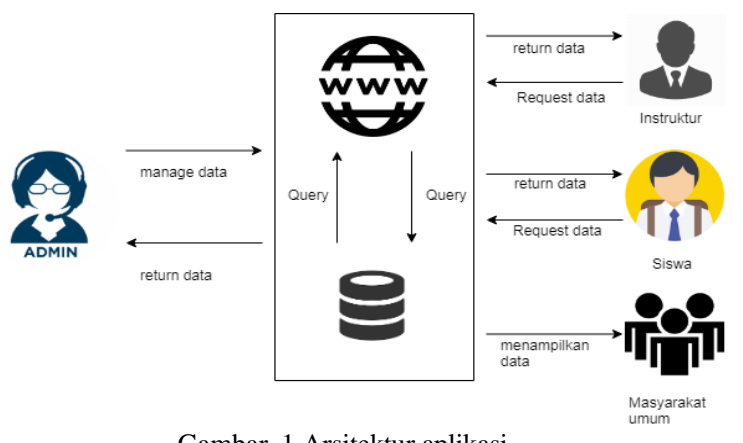

Gambar. 1 Arsitektur aplikasi

a. Pada aplikasi ini, admin dapat melakukan manajemen data. Admin dapat menerima dan menolak pengajuan, menambahkan jurusan dan sub jurusan, mengubah status calon siswa menjadi siswa, menerima atau menolak calon siswa, menambahkan jadwal serta mengeluarkan sertifikat dan dapat mengubah data instruktur.

b. Instruktur dapat memberikan pengumuman, melihat siswa dan melihat data alumni.

c. Siswa dapat mengakses sistem dengan mendaftar sebagai calon siswa di halaman register, kemudian login kedalam sistem. Siswa dapat melihat biodata siswa, status siswa ditolak atau lulus, serta dapat memilih kejuruan yang diinginkan.

d. Pada sistem ini, masyarakat umum hanya dapat melihat galeri jurusan, pengumuman serta mencari alumni dengan memasukkan data alumni yang dicari.

e. Sistem ini terkoneksi internet dan terhubung dengan database tempat penyimpanan data.

2. Diagram Business Process Modeling Notation (BPMN)

Diagram BPMN adalah representasi grafis untuk menentukan proses bisnis dalam model proses bisnis. Diagram BPMN yang akan dibangun dapat dilihat pada Gambar 2 dibawah ini:

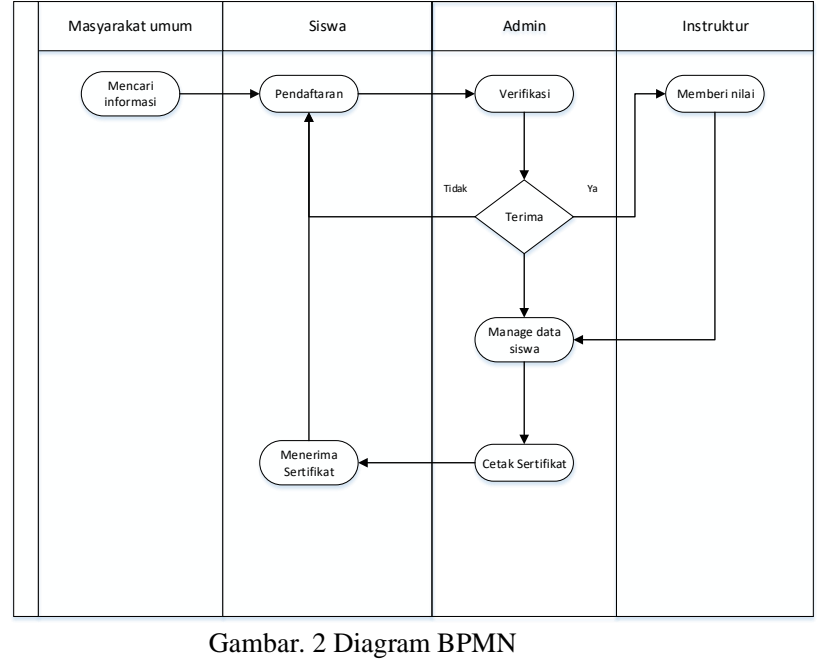

III. HASIL DAN PEMBAHASAN

\section{A. Hasil Perancangan Antarmuka Aplikasi}

Berikut adalah pemaparan perancangan antarmuka aplikasi Sistem Informasi Manajemen Pleatihan pada Kantor Unit Pelaksanaa Teknis Latihan Kerja Industri (UPT LKI) Provinsi Kalimantan Barat:

\section{Tampilan Antarmuka Halaman Home}

Halaman home merupakan halaman muka dari situs web. Halaman ini bertujuan untuk menampilkan informasi, galeri dan kontak dari pengguna web tersebut. Pada web UPT LKI, halaman home terdiri dari informasi lokasi, kontak UPT LKI, email, serta galeri foto dari kegiatan yang telah dilakukan. Tampilan Antarmuka Halaman Home pada UPT LKI dapat dilihat pada Gambar 3.
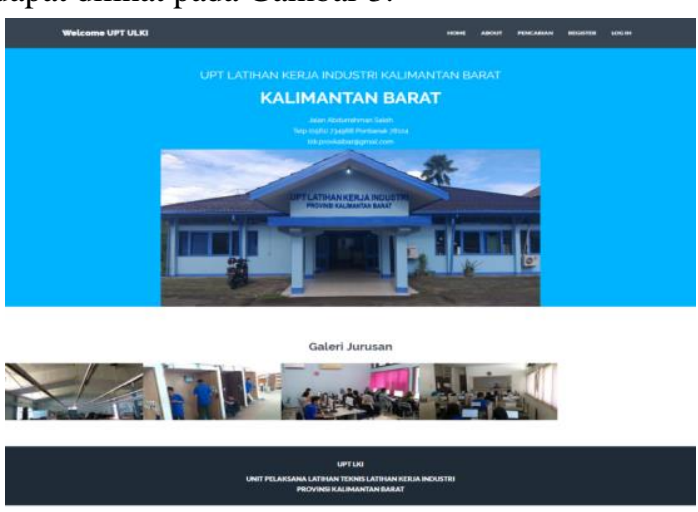

Gambar. 3 Antarmuka halaman home

2. Tampilan Antarmuka Halaman About

Halaman about merupakan halaman yang memiliki peranan penting terhadap informasi UPT LKI. Halaman ini digunakan untuk menampilkan identitas dari UPT LKI. Halaman ini terdiri dari informasi Visi, Misi, Tugas pokok dan Fungsi serta alamat dari UPT LKI. Tampilan antarmuka halaman about dapat dilihat pada Gambar 4. 


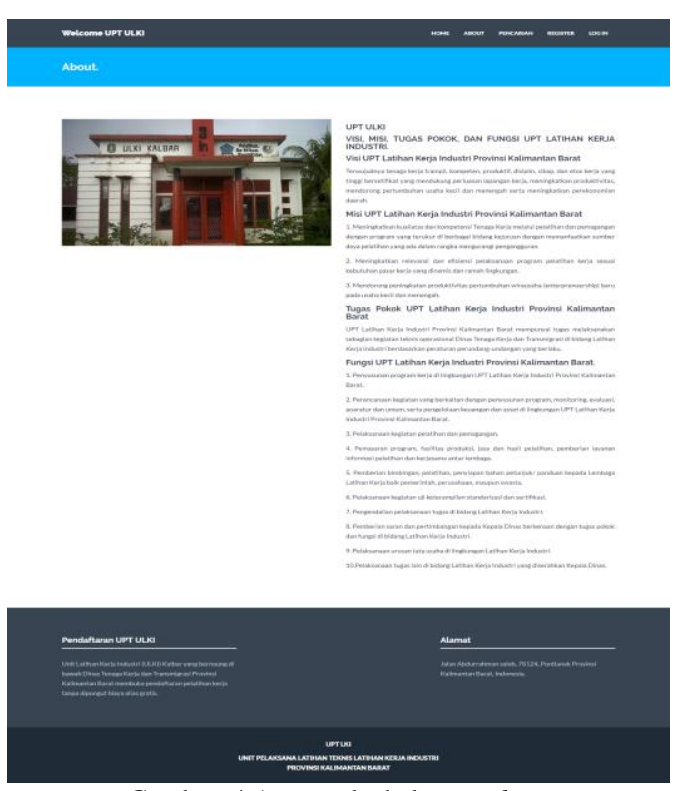

Gambar. 4 Antarmuka halaman about

3. Tampilan Antarmuka Halaman Pencarian

Halaman pencarian digunakan untuk mencari informasi alumni dari UPT LKI. Halaman ini dapat digunakan pihak perusahaan untuk mencari alumni dari kemampuan jurusan yang dibutuhkan. Tampilan dari halaman pencarian dapat dilihat pada Gambar 5.
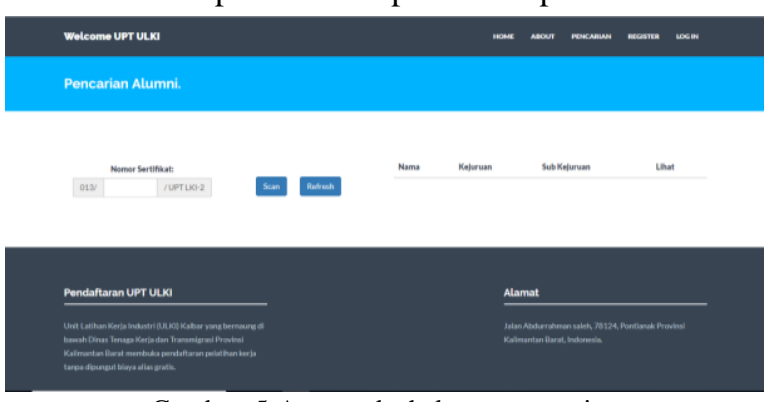

Gambar. 5 Antarmuka halaman pencarian

4. Tampilan Antarmuka Halaman Register

Halaman register merupakan suatu halaman web yang digunakan oleh pengguna untuk mendaftarkan akun baru sebagai siswa di UPT LKI. Dengan akun baru tersebut, pengguna dapat mendaftar jurusan pelatihan yang akan di ikuti. Adapun isian data yang diperlukan oleh pengguna untuk diisi terdiri kolom nama, alamat, tempat dan tanggal lahir, agama, status, No KTP, email dan password. Pengguna juga harus mengunggah foto dan jurusan yang akan diikuti. Setelah pengguna mengisi dan mengklik tombol tambah, akun baru pengguna sebagai ssiwa telah terbentuk. Adapun tampilan antarmuka halaman register dapat dilihat pada Gambar 6 .

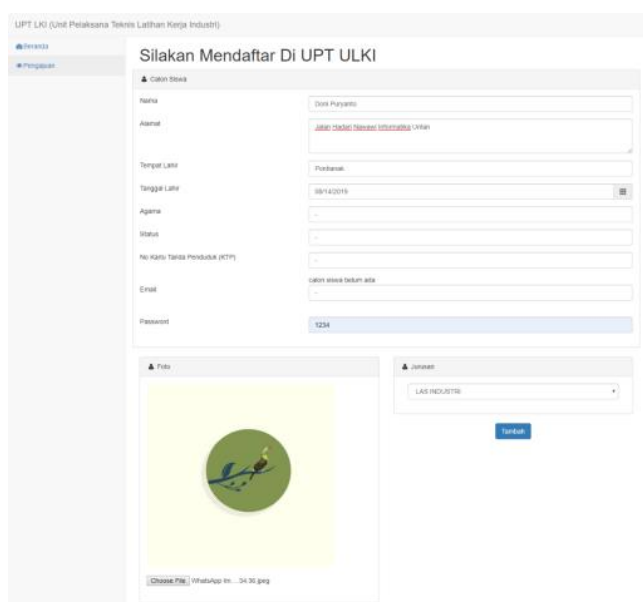

Gambar. 6 Antarmuka halaman register

5. Tampilan Antarmuka Halaman Login

Halaman $\log$ in merupakan halaman yang digunakan untuk memverifikasi pengguna agar dapat mengakses halaman beranda pengguna. Pengguna dapat memasukan NIK dan password untuk log in. Tampilan antarmuka halaman log in dapat dilihat pada Gambar 7.

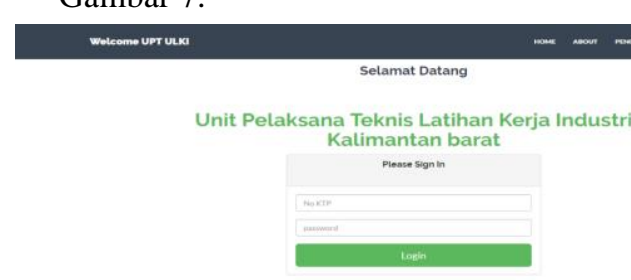

Gambar .7 Antarmuka halaman login

6. Tampilan Antarmuka Halaman Beranda Siswa

Halaman beranda siswa menampilkan status dari jurusan yang di pilih. Pengguna yang belum di konfirmasi oleh admin akan di tampilkan status menunggu. Untuk pengguna yang telah di terima atau di tolak, akan di tampilkan status sesuai dengan konfirmasi yang diterima dari admin. Tampilan antarmuka halaman berandan pengguna dapat dilihat pada Gambar 8.

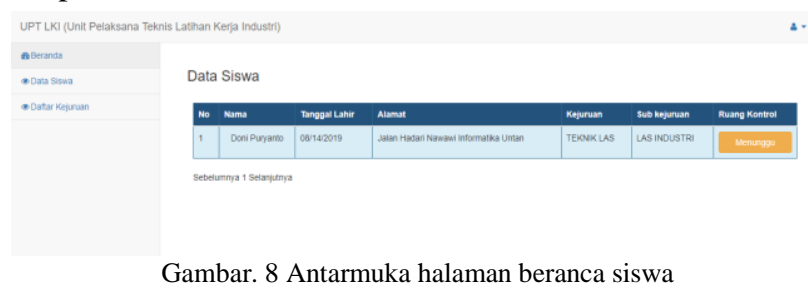

7. Tampilan Antarmuka Halaman Biodata Siswa

Antarmuka halaman biodata siswa pengguna digunakan untuk menampilkan profil dari pengguna.. Tampilan antarmuka halaman data siswa dapat dilihat pada Gambar 9 berikut. 


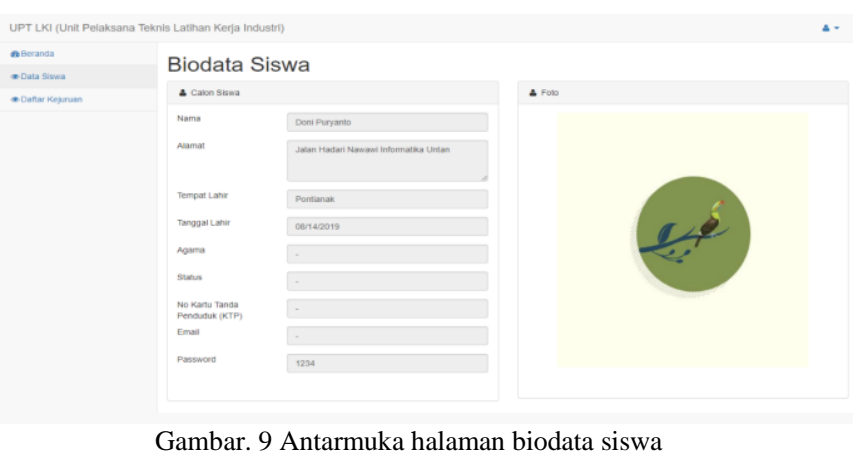

8. Tampilan Antarmuka Halaman Daftar Kejuruan Siswa

Halaman kejuruan pengguna digunakan untuk mendaftar jurusan pelatihan yang akan di ikuti. Setiap pengguna hanya dapat mengikuti satu jurusan dalam satu kali pelatihan. Adapun pengguna yang sudah memilih jurusan tidak dapat memilih jurusan kedua. Tampilan antarmuka halaman daftar kejuruan pengguna dapat dilihat pada Gambar 10 di bawah ini.

\section{Gambar. 10 Antarmuka halaman daftar kejuruan siswa}

9. Tampilan Antarmuka Halaman Dashboard Admin

Halaman dashboard admin menampilkan rangkuman berupa jumlah dari calon siswa, siswa, alumni dan pemohon yang di tolak. Pada halaman ini juga dapat memberikan pengumuman kepada calon siswa baru serta alumni yang mengambil sertifikat. Tampilan antarmuka dashboard admin dapat dilihat pada Gambar 11.

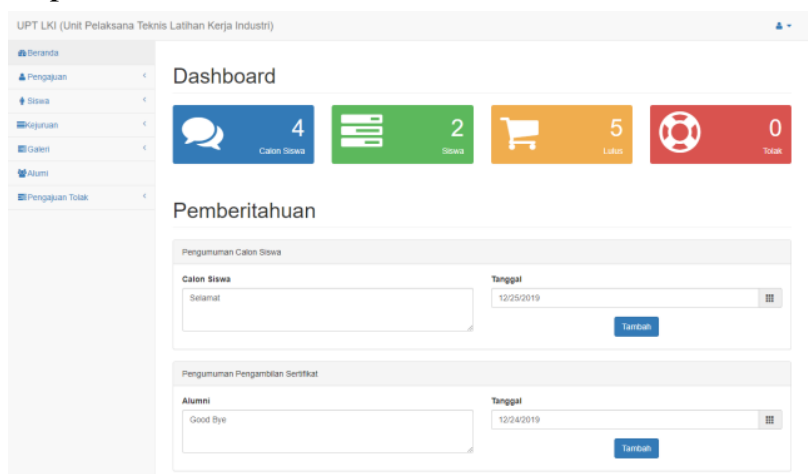

Gambar. 11 Antarmuka halaman dashboard admin

10. Tampilan Antarmuka Halaman Pengajuan Admin Halaman pengajuan admin merupakan suatu halaman situs web dimana admin dapat menerima atau menolak calon siswa. Pada halaman ini admin dapat melihat data calon siswa berupa nama, umur, tanggal lahir, alamat, kejuruan dan sub kejuruan. Tampilan antarmuka halaman pengajuan admin dapat dilihat pada Gambar 12.

\section{Gambar 12 Antarmuka halaman pengajuan admin}

11. Tampilan Antarmuka Halaman Siswa Admin

Halaman siswa menampilkan siswa yang sedang belajar ataupun telah selesai dari latihan kerja industri. Admin dapat melihat data siswa ataupun menambahkan kompotensi yang telah diikuti oleh siswa. Tampilan antarmuka halaman siswa admin dapat dilihat pada Gambar 13.

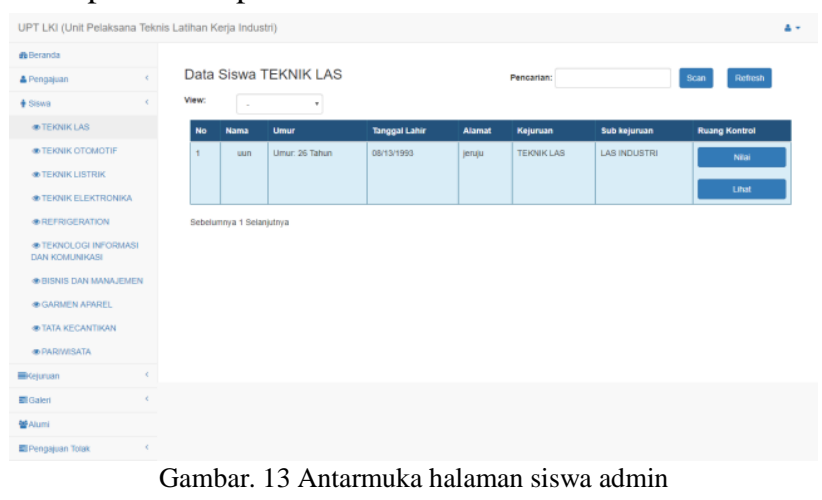

12. Tampilan Antarmuka Halaman Kejuruan Admin Halaman kejuruan admin menampilkan kejuruan dan sub kejuruan yang dapat diambil. Adapun kejuruan terdapat pada menu navigasi di sebelah kiri. Admin dapat menambahkan beberapa sub kejuruan, mengubah dan melihat isi dari sub kejuruan. Adapun tampilan antarmuka halaman kejuruan admin dapat dilihat pada Gambar 14.

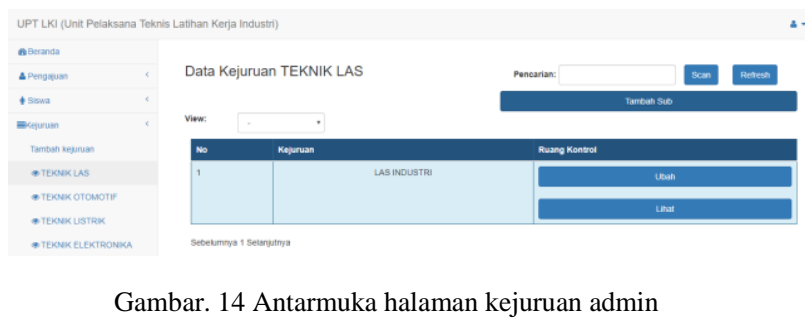

13. Tampilan Antarmuka Halaman Galeri Admin

Halaman galeri admin menampilkan foto atau dokumentasi kegiatan yang dilakukan oleh UPT LKI. Dokumentasi kegiatan tersebut dipisahkan berdasarkan kejuruan yang digunakan. Untuk menambahkan foto terbaru, admin harus memilih dari kejuruan mana foto tersebut diambil. Kemudian admin akan mengupload foto tersebut untuk ditampilkan pada halaman beranda. Tampilan antarmuka halaman galeri admin dapat dilihat pada Gambar 15. 


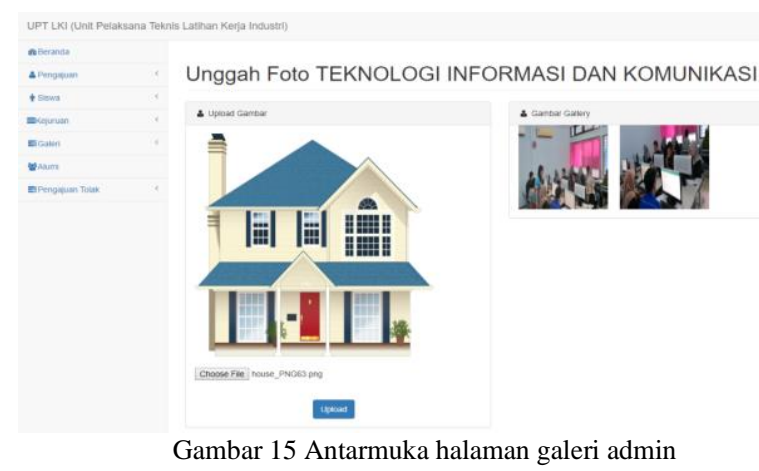

14. Tampilan Antarmuka Halaman Alumni Admin Halaman alumni admin menampilkan data dari alumni UPT LKI. Admin dapat mencetak sertifikat dan melihat data pelatihan alumni. Halaman ini dilengkapi dengan pencarian untuk mencari alumni berdasarkan nama. Tampilan antarmuka halaman alumni oleh admin dapat dilihat pada Gambar 16.

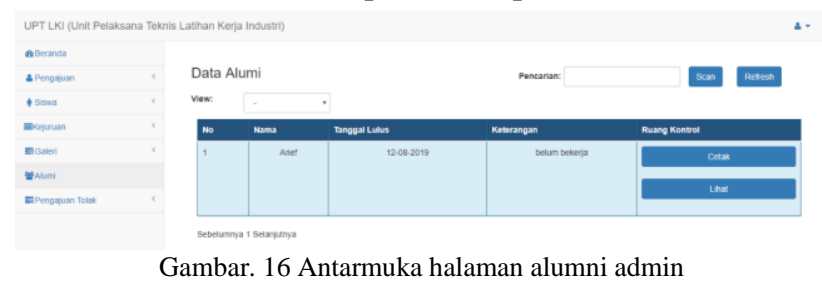

15. Tampilan Antarmuka Halaman Tolak Pengajuan Admin

Halaman tolak pengajuan menampilkan data nama nama calon siswa yang di tolak melalui antarmuka halaman pengajuan. Tampilan halaman pengajuan dapat dilihat pada Gambar 17.

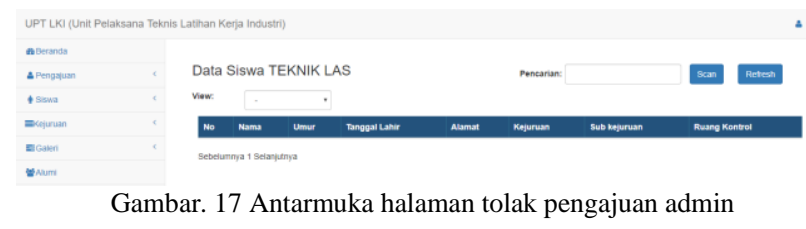

16. Tampilan Antarmuka Halaman Instruktur Admin

Halaman beranda instruktur menampilkan pengumuman dari admin. Hal ini ditujukan untuk memberikan informasi tentang UPT LKI secara online. Tampilan antarmuka halaman beranda instruktur dapat dilihat pada Gambar 18 .

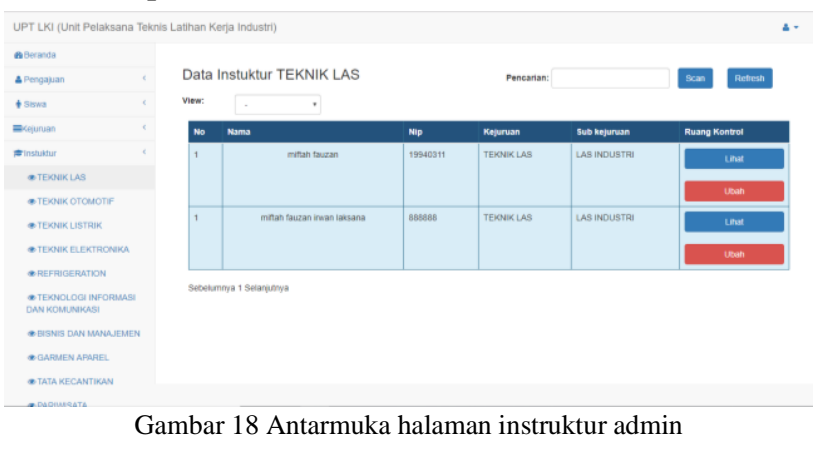

17. Tampilan Antarmuka Halaman Beranda Instruktur

Halaman beranda instruktur menampilkan pengumuman dari admin. Hal ini ditujukan untuk memberikan informasi tentang UPT LKI secara online.
Tampilan antarmuka halaman beranda instruktur dapat dilihat pada Gambar 19.

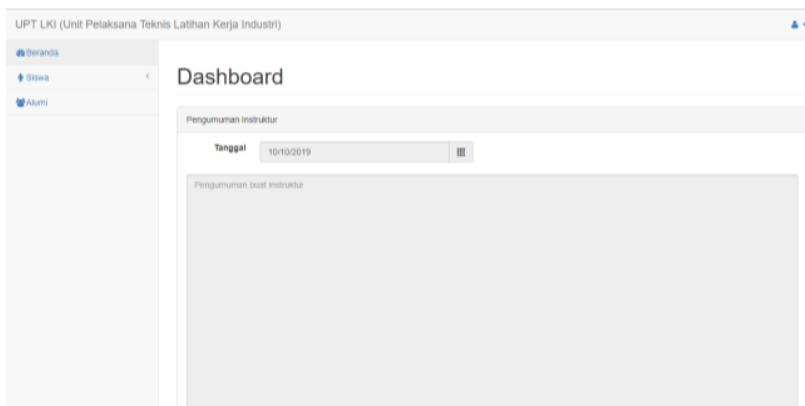

Gambar. 19 Antarmuka halaman beranda instruktur

18. Tampilan Antarmuka Halaman Tambah Nilai Siswa

Halaman penilaian siswa terdiri dari list siswa yang mengikuti pelatihan sesuai dengan bidang kejuruan yang diikut. Pada halaman ini, instruktur pelatihan dapat melihat data siswa dan memasukan penilaian. Tampilan antarmuka halaman data siswa dapat dilihat pada Gambar 20.

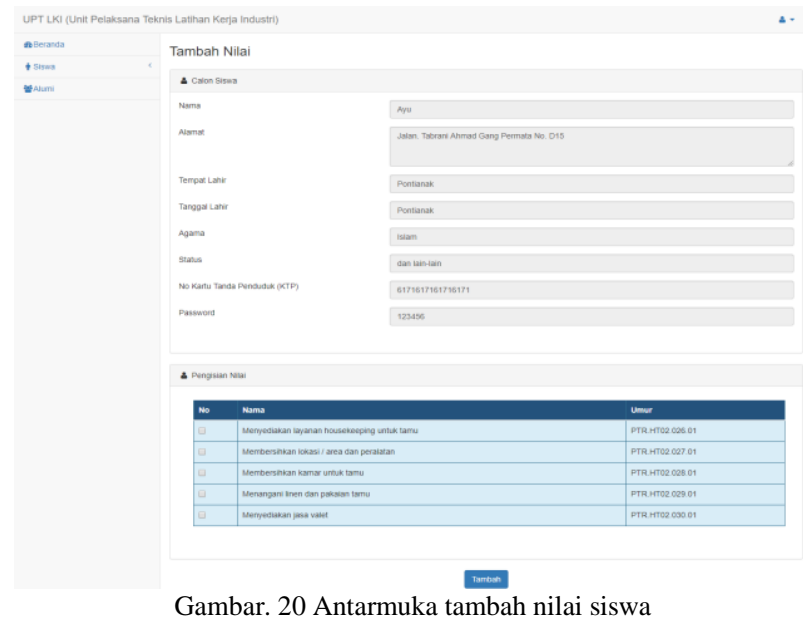

19. Tampilan Antarmuka Halaman Alumni Instruktur

Halaman daftar alumni menampilkan seluruh alumni yang pernah mengikuti pelatihan yang diajarkan oleh masing masing instruktur. Pada halaman ini, instruktur dapat melihat penilaian yang diberikan untuk tiap tiap alumninya. Tampilan antarmuka halaman daftar alumni dapat dilihat pada Gambar 21.

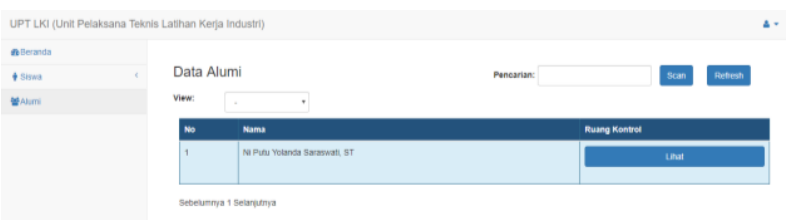

Gambar. 21 Antarmuka halaman alumni instruktur

\section{B. Hasil Pengujian Black Box}

Berikut ini hasil pengujian yang dilakukan dengan menggunakan metode blackbox. 
TABEL I

HASIL PENGUJIAN BLACK-BOX LOGIN

\begin{tabular}{|c|c|c|c|c|}
\hline Menu & Masukan & \multicolumn{2}{|c|}{ Contoh Data } & Hasil \\
\hline \multirow{8}{*}{$\begin{array}{l}.5 \\
0 \\
3 \\
3\end{array}$} & Data & No KTP & & \multirow{6}{*}{$\begin{array}{c}\text { Tidak } \\
\text { berhasil } \\
\text { login }\end{array}$} \\
\hline & Kosong & Password & & \\
\hline & \multirow[b]{2}{*}{$\begin{array}{l}\text { Data } \\
\text { benar, } \\
\text { salah satu } \\
\text { data } \\
\text { kosong }\end{array}$} & No KTP & admin@gmail.com & \\
\hline & & Password & & \\
\hline & \multirow{2}{*}{$\begin{array}{l}\text { Data salah } \\
\text { semua }\end{array}$} & No KTP & Admin.com & \\
\hline & & Password & $\mathrm{Xxx}$ & \\
\hline & \multirow{2}{*}{$\begin{array}{l}\text { Data } \\
\text { lengkap } \\
\text { dan benar }\end{array}$} & No KTP & admin@gmail.com & \multirow{2}{*}{$\begin{array}{c}\text { Berhasil } \\
\text { login }\end{array}$} \\
\hline & & Password & $\operatorname{admin} 123$ & \\
\hline
\end{tabular}

TABEL II

HASIL PENGUJIAN BLACK BOX REGISTRASI SISWA

\begin{tabular}{|c|c|c|c|}
\hline Masukan & \multicolumn{2}{|c|}{ Contoh data } & $\begin{array}{c}\text { Hasil } \\
\text { Eksekusi }\end{array}$ \\
\hline \multirow{11}{*}{$\begin{array}{l}\text { Seluruh } \\
\text { Kolom isian } \\
\text { kosong }\end{array}$} & Nama & & \multirow{11}{*}{$\begin{array}{l}\text { Tidak } \\
\text { berhasil } \\
\text { terdaftar }\end{array}$} \\
\hline & Alamat & & \\
\hline & Tempat Lahir & & \\
\hline & Tanggal Lahir & & \\
\hline & Agama & & \\
\hline & Status & & \\
\hline & No KTP & & \\
\hline & Email & & \\
\hline & Password & & \\
\hline & Foto & & \\
\hline & Jurusan & & \\
\hline & Nama & Joko Setiadi & \\
\hline & Alamat & $\begin{array}{l}\text { Jalan A.Yani Gg. } \\
\text { Sepakat II }\end{array}$ & \\
\hline & Tempat Lahir & Pontianak & \\
\hline & Tanggal Lahir & $2 / 2 / 1999$ & \\
\hline Salah satu & Agama & Islam & \\
\hline $\begin{array}{l}\text { Salah satu } \\
\text { kolom isian }\end{array}$ & Status & Belum Menikah & $\begin{array}{l}\text { Tidak } \\
\text { herhasil }\end{array}$ \\
\hline $\begin{array}{l}\text { Kolom islan } \\
\text { kosong }\end{array}$ & No KTP & $\begin{array}{l}617101020299001 \\
0\end{array}$ & $\begin{array}{l}\text { berhasil } \\
\text { terdaftar }\end{array}$ \\
\hline & email & $\begin{array}{l}\text { jokosetiadi@gmai } \\
\text { 1.com }\end{array}$ & \\
\hline & Password & 1234 & \\
\hline & Foto & foto.jpg & \\
\hline & Jurusan & Las Industri & \\
\hline $\begin{array}{l}\text { Kolom isian } \\
\text { KTP di isi } \\
\text { selain angka }\end{array}$ & No KTP & $61710102 q w$ & $\begin{array}{l}\text { Tidak } \\
\text { berhasil } \\
\text { menambah } \\
\text { kan kolom } \\
\text { isian KTP } \\
\end{array}$ \\
\hline & Nama & Joko Setiadi & \\
\hline & Alamat & $\begin{array}{l}\text { Jalan A.Yani Gg. } \\
\text { Sepakat II }\end{array}$ & \\
\hline & Tempat Lahir & Pontianak & \\
\hline & Tanggal Lahir & $2 / 2 / 1999$ & \\
\hline $\begin{array}{l}\text { Seluruh } \\
\text { kolom di isi }\end{array}$ & Agama & Islam & Berhasil \\
\hline dengan tipe & Status & Belum Menikah & an akun \\
\hline data yang & No KTP & $\begin{array}{l}617101020299001 \\
0\end{array}$ & calon siswa \\
\hline & email & $\begin{array}{l}\text { jokosetiadi@gmai } \\
\text { 1.com }\end{array}$ & \\
\hline & Password & 1234 & \\
\hline & Foto & foto.jpg & \\
\hline & Jurusan & Las Industri & \\
\hline
\end{tabular}

TABEL III

HASIL PENGUJIAN BLACK BOX TAMBAH KEJURUAN

\begin{tabular}{|c|c|c|c|}
\hline Masukan & \multicolumn{2}{|c|}{ Contoh data } & $\begin{array}{c}\text { Hasil } \\
\text { Eksekusi }\end{array}$ \\
\hline \multirow{7}{*}{$\begin{array}{l}\text { Seluruh } \\
\text { kolom isian } \\
\text { kosong }\end{array}$} & Kejuruan & & \multirow{7}{*}{$\begin{array}{c}\text { Tidak } \\
\text { Berhasil }\end{array}$} \\
\hline & Sub Kejuruan & & \\
\hline & Unit Kompetensi & & \\
\hline & Kode Unit & & \\
\hline & Jam Teori & & \\
\hline & Jam Praktek & & \\
\hline & Jumlah Jam & & \\
\hline \multirow{7}{*}{$\begin{array}{l}\text { Salah satu } \\
\text { kolom isian } \\
\text { kosong }\end{array}$} & Kejuruan & $\begin{array}{l}\text { Teknik } \\
\text { Pengemasan } \\
\text { Makanan }\end{array}$ & \multirow{7}{*}{$\begin{array}{c}\text { Tidak } \\
\text { Berhasil }\end{array}$} \\
\hline & Sub Kejuruan & Makanan Cemilan & \\
\hline & Unit Kompetensi & $\begin{array}{l}\text { Pengolahan } \\
\text { makanan kecil }\end{array}$ & \\
\hline & Kode Unit & & \\
\hline & Jam Teori & 12 & \\
\hline & Jam Praktek & 12 & \\
\hline & Jumlah Jam & 24 & \\
\hline \multirow{7}{*}{$\begin{array}{c}\text { Seluruh } \\
\text { kolom isian } \\
\text { diisi } \\
\text { dengan } \\
\text { benar }\end{array}$} & Kejuruan & $\begin{array}{l}\text { Teknik } \\
\text { Pengemasan } \\
\text { Makanan }\end{array}$ & \multirow{7}{*}{$\begin{array}{l}\text { Berhasil } \\
\text { menambah } \\
\text { kan juruan }\end{array}$} \\
\hline & Sub Kejuruan & Makanan Cemilan & \\
\hline & Unit Kompetensi & $\begin{array}{l}\text { Pengolahan } \\
\text { makanan kecil }\end{array}$ & \\
\hline & Kode Unit & 110011 & \\
\hline & Jam Teori & 12 & \\
\hline & Jam Praktek & 12 & \\
\hline & Jumlah Jam & 24 & \\
\hline
\end{tabular}

\section{Hasil Pengujian User Acceptance Test (UAT)}

Berikut ini adalah hasil dari rekapitulasi penilaian terhadap pengguna aplikasi Sistem Informasi Manajemen UPTLKI Provinsi Kalimantan Barat menggunakan perhitungan skala likert dapat dilihat pada Tabel IV

TABEL IV

REKAP PERHITUNGAN USER ACCEPTANCE TEST

\begin{tabular}{|c|c|c|c|c|c|c|c|}
\hline \multirow{3}{*}{$\begin{array}{c}\text { No } \\
\cdot\end{array}$} & $\begin{array}{c}\text { Aspek / } \\
\text { Pertanyaan }\end{array}$ & $\begin{array}{c}\text { SB } \\
(\mathbf{5})\end{array}$ & $\begin{array}{c}\text { B } \\
(4)\end{array}$ & $\begin{array}{c}\text { CB } \\
(3)\end{array}$ & $\begin{array}{c}\text { KB } \\
(2)\end{array}$ & $\begin{array}{c}\text { TB } \\
\text { (1) }\end{array}$ & $\begin{array}{c}\text { Pers } \\
\text { se } \\
\text { Like } \\
\text { rt }\end{array}$ \\
\hline
\end{tabular}

\begin{tabular}{|c|l|l|l|l|l|l|l|}
\hline Aspek rekayasa perangkat lunak & & & & & & \\
\hline 1. & $\begin{array}{l}\text { Apakah } \\
\text { aplikasi } \\
\text { tersebut } \\
\text { mudah } \\
\text { digunakan? }\end{array}$ & 6 & 12 & 2 & 0 & 0 & $\begin{array}{c}84,0 \\
0 \%\end{array}$ \\
\hline 2. & $\begin{array}{l}\text { Apakah } \\
\text { aplikasi } \\
\text { tersebut dapat } \\
\text { digunakan } \\
\text { dengan } \\
\text { lancar? }\end{array}$ & 7 & 7 & 6 & 0 & 0 & $\begin{array}{c}81,0 \\
0 \%\end{array}$ \\
\hline 3. & $\begin{array}{l}\text { Apakah fitur } \\
\text { fitur pada } \\
\text { aplikasi dapat } \\
\text { diakses } \\
\text { dengan } \\
\text { mudah? }\end{array}$ & 6 & 9 & 5 & 0 & 0 & $\begin{array}{c}81,0 \\
0 \%\end{array}$ \\
\hline 4. & $\begin{array}{l}\text { Apakah } \\
\text { tampilan } \\
\text { pengguna } \\
\text { cukup halus? }\end{array}$ & 4 & 12 & 4 & 0 & 0 & $\begin{array}{c}80,0 \\
0 \%\end{array}$ \\
\hline 5. & $\begin{array}{l}\text { Apakah } \\
\text { aplikasi } \\
\text { cukup } \\
\text { responsif? }\end{array}$ & 6 & 12 & 2 & 0 & 0 & $\begin{array}{c}84,0 \\
0 \%\end{array}$ \\
\hline Aspek fungsionalitas & & & & & \\
\hline
\end{tabular}




\begin{tabular}{|c|c|c|c|c|c|c|c|}
\hline \multirow[b]{2}{*}{$\begin{array}{l}\text { No } \\
\text {. }\end{array}$} & \multirow[b]{2}{*}{$\begin{array}{c}\text { Aspek / } \\
\text { Pertanyaan }\end{array}$} & \multicolumn{5}{|c|}{ Nilai Pengujian } & \multirow{2}{*}{$\begin{array}{l}\text { Pers } \\
\text { enta } \\
\text { se } \\
\text { Like } \\
\text { rt }\end{array}$} \\
\hline & & $\begin{array}{l}\text { SB } \\
\text { (5) }\end{array}$ & $\begin{array}{l}\text { B } \\
\text { (4) }\end{array}$ & $\begin{array}{l}\text { CB } \\
\text { (3) }\end{array}$ & $\begin{array}{l}\mathbf{K B} \\
\text { (2) }\end{array}$ & $\begin{array}{l}\text { TB } \\
\text { (1) }\end{array}$ & \\
\hline 6. & $\begin{array}{l}\text { Apakah } \\
\text { aplikasi sudah } \\
\text { dapat } \\
\text { melakukan } \\
\text { registrasi } \\
\text { peserta } \\
\text { dengan baik? }\end{array}$ & 8 & 7 & 5 & 0 & 0 & $\begin{array}{c}83,0 \\
0 \%\end{array}$ \\
\hline 7. & $\begin{array}{l}\text { Apakah } \\
\text { aplikasi } \\
\text { menampilkan/ } \\
\text { memberikan } \\
\text { informasi } \\
\text { dengan baik? }\end{array}$ & 7 & 10 & 3 & 0 & 0 & $\begin{array}{c}84,0 \\
0 \%\end{array}$ \\
\hline 8. & $\begin{array}{l}\text { Apakah } \\
\text { aplikasi dapat } \\
\text { menampilkan } \\
\text { data alumni } \\
\text { dengan baik? }\end{array}$ & 6 & 10 & 4 & 0 & 0 & $\begin{array}{l}82,0 \\
0 \%\end{array}$ \\
\hline 9. & $\begin{array}{l}\text { Apakah user } \\
\text { dapat login } \\
\text { dengan baik }\end{array}$ & 10 & 7 & 3 & 0 & 0 & $\begin{array}{l}87,0 \\
0 \%\end{array}$ \\
\hline 10. & $\begin{array}{l}\text { Apakah galeri } \\
\text { sudah } \\
\text { menampilkan } \\
\text { gambar } \\
\text { dengan baik? }\end{array}$ & 8 & 7 & 5 & 0 & 0 & $\begin{array}{l}83,0 \\
0 \%\end{array}$ \\
\hline 11. & $\begin{array}{l}\text { Apakah } \\
\text { admin dapat } \\
\text { dengan } \\
\text { mudah } \\
\text { melakukan } \\
\text { proses } \\
\text { manajemen } \\
\text { jadwal dan } \\
\text { kejuruan? } \\
\end{array}$ & 7 & 11 & 2 & 0 & 0 & $\begin{array}{l}85,0 \\
0 \%\end{array}$ \\
\hline 12. & $\begin{array}{l}\text { Apakah } \\
\text { admin dapat } \\
\text { dengan } \\
\text { mudah } \\
\text { melakukan } \\
\text { proses } \\
\text { manajemen } \\
\text { alumni? }\end{array}$ & 8 & 8 & 4 & 0 & 0 & $\begin{array}{l}84,0 \\
0 \%\end{array}$ \\
\hline 13. & $\begin{array}{l}\text { Apakah siswa } \\
\text { dapat malihat } \\
\text { status } \\
\text { pelatihan } \\
\text { dengan } \\
\text { mudah? }\end{array}$ & 6 & 11 & 3 & 0 & 0 & $\begin{array}{l}83,0 \\
0 \%\end{array}$ \\
\hline 14. & $\begin{array}{l}\text { Apakah siswa } \\
\text { dapat } \\
\text { memilih } \\
\text { kejuruan } \\
\text { dengan } \\
\text { mudah? } \\
\end{array}$ & 5 & 9 & 6 & 0 & 0 & $\begin{array}{l}79,0 \\
0 \%\end{array}$ \\
\hline \multicolumn{8}{|c|}{ Aspek komunikasi visual } \\
\hline 15. & $\begin{array}{l}\text { Apakah } \\
\text { tampilan } \\
\text { antarmuka } \\
\text { aplikasi sudah } \\
\text { baik? }\end{array}$ & 3 & 14 & 3 & 0 & 0 & $\begin{array}{l}80,0 \\
0 \%\end{array}$ \\
\hline 16. & $\begin{array}{l}\text { Apakah } \\
\text { tampilan } \\
\text { menu aplikasi } \\
\text { sudah cukup } \\
\text { baik? }\end{array}$ & 5 & 11 & 4 & 0 & 0 & $\begin{array}{l}81,0 \\
0 \%\end{array}$ \\
\hline 17. & $\begin{array}{l}\text { Apakah form } \\
\text { pengisian } \\
\text { data sudah } \\
\text { cukup baik? }\end{array}$ & 8 & 8 & 4 & 0 & 0 & $\begin{array}{l}84,0 \\
0 \%\end{array}$ \\
\hline
\end{tabular}

\begin{tabular}{|c|c|c|c|c|c|c|c|}
\hline \multirow[b]{2}{*}{$\begin{array}{c}\text { No } \\
\text { · }\end{array}$} & \multirow[b]{2}{*}{$\begin{array}{c}\text { Aspek / } \\
\text { Pertanyaan }\end{array}$} & \multicolumn{5}{|c|}{ Nilai Pengujian } & \multirow{2}{*}{$\begin{array}{c}\text { Pers } \\
\text { enta } \\
\text { se } \\
\text { Like } \\
\text { rt }\end{array}$} \\
\hline & & $\begin{array}{l}\text { SB } \\
(5)\end{array}$ & $\begin{array}{l}\text { B } \\
\text { (4) }\end{array}$ & $\begin{array}{l}\text { CB } \\
\text { (3) }\end{array}$ & $\begin{array}{l}\text { KB } \\
\text { (2) }\end{array}$ & $\begin{array}{l}\text { TB } \\
\text { (1) }\end{array}$ & \\
\hline 18. & $\begin{array}{l}\text { Apakah jenis } \\
\text { dan ukuran } \\
\text { font yang } \\
\text { digunakan } \\
\text { mudah } \\
\text { dibaca? }\end{array}$ & 8 & 8 & 4 & 0 & 0 & $\begin{array}{l}84,0 \\
0 \%\end{array}$ \\
\hline 19. & $\begin{array}{l}\text { Apakah } \\
\text { kombinasi } \\
\text { warna pada } \\
\text { tampilan } \\
\text { aplikasi sudah } \\
\text { cukup baik? }\end{array}$ & 5 & 12 & 3 & 0 & 0 & $\begin{array}{l}82,0 \\
0 \%\end{array}$ \\
\hline 20. & $\begin{array}{l}\text { Apakah } \\
\text { respon } \\
\text { aplikasi } \\
\text { terhadap } \\
\text { input yang } \\
\text { dilakukan } \\
\text { sudah baik? }\end{array}$ & 9 & 8 & 3 & 0 & 0 & $\begin{array}{l}86,0 \\
0 \%\end{array}$ \\
\hline \multicolumn{7}{|c|}{ Total Persentase (\%) } & $\begin{array}{l}82,8 \\
5 \%\end{array}$ \\
\hline
\end{tabular}

Berdasarkan hasil perhitungan skala likert di atas, diketahui bahwa dari 20 responden total persentase yang dihasilkan adalah $\mathbf{8 2 , 8 5 \%}$

\section{Analisa Hasil Pengujian}

Berikut ini adalah hasil pengujian aplikasi Sistem Informasi Manajemen UPTLKI Provinsi Kalimantan Barat yang dilakukan melalui pengujian black-box dan pengujian UAT:

1. Dari hasil pengujian blackbox diketahui bahwa aplikasi dapat dijalankan jika data yang dimasukkan sesuai dan data tidak boleh kosong.

2. Dari hasil pengujian UAT didapatkan rata-rata persentase yaitu $82,85 \%$ dan berada didalam kategori sangat baik.

3. Dalam aspek rekayasa perangkat lunak, didapatkan hasil bawa aplikasi tersebut cukup mudah digunakan dan cukup responsif. Hal ini ditunjukan dari nilai persentasi yang lebih tinggi serta jumlah responden yang memberikan penilaian cukup benar sebanyak 2 orang. Pada penilaian kelancaran aplikasi, akses fitur dan kehalusan mendapat persentase lebih rendah. Penilaian kelancaran aplikasi dipengaruhi oleh beberapa aspek seperti kualitas jaringan internet serta kemampuan pemrosesan dari hosting yang digunakan. Penilaian akses fitur dan kehalusan dipengaruhi oleh perangkat yang digunakan oleh pengguna.

4. Dalam aspek fungsionalitas terdapat sembilan penilaian yaitu penilaian registrasi, informasi, menampilkan data alumni, menampilkan galeri, manajemen proses kejuruan dan penjadwalan, manajemen alumni, status penerimaan siswa, memilih kejuruan dan fungsionalitas login. Fungsionalitas login mendapat nilai persentase tertinggi sebanyak $87 \%$ dengan 10 responden yang memberikan penilaian sangat baik, 7 responden memberikan penilaian baik dan 3 responden memberikan penilaian cukup baik. Penilaian pemilihan kejuruan mendapatkan persentase nilai yang paling rendah dalam aspek fungsionalitas. 
Hal ini dikarenakan pengguna (siswa) hanya dapat memilih kejuruan setelah dilakukan penolakan atau kelulusan pendidikan, sehingga pengguna hanya dapat mengikuti satu kejuruan dalam satu waktu. Pembatasan ini dimaksudkan agar siswa dapat fokus ke satu kejuruan terlebih dahulu sebelum mencoba kejuruan lain. Namun hal ini malah berdampak pada sentimen kurang baik pada penilaian aplikasi.

5. Dalam aspek komunikasi visual terdapat enam penilaian yang dilakukan yaitu tampilan, menu, pengisian form, jenis font, warna tampilan dan respon terhadap input. Penilaian respon terhadap input yang di terima mendapatkan nilai persentase yang paling tinggi. Sedangkan tampilan mendapat nilai persentasi yang paling rendah dalam aspek ini.

\section{KESIMPULAN}

Adapun kesimpulan dari hasil penelitian yang berjdul "sistem informasi manajemen pelatihan pada kantor unit pelaksana teknis latihan kerja industri (UPT LKI) provinsi Kalimantan Barat" yang telah dilakukan adalah sistem informasi manajemen pelatihan pada kantor unit pelaksana teknis latihan kerja industri (UPT LKI) provinsi Kalimantan Barat yang berhasil dibangun dapat dimanfaatkan sebagai sarana penyajian informasi terkait pembukaan pelatihan untuk mengikuti pelatihan pada kantor UPT LKI provinsi Kalimantan Barat. Berdasarkan hasil pengujian dengan black box sistem informasi manajemen pelatihan pada kantor unit pelaksana teknis latihan kerja industri (UPT LKI) provinsi kalimantan Barat yang dibangun dapat berjalan dengan baik. Berdasarkan hasil pengujian UAT dengan perhitungan skala likert dapat diketahui persentase yang didapat yaitu $82,85 \%$ dan dikatogorikan sangat baik.

\section{DAFTAR PUSTAKA}

[1] S. M. Metev and V. P. Veiko, Laser Assisted Microtechnology, 2nd ed., R. M. Osgood, Jr., Ed. Berlin, Germany: SpringerVerlag, 1998.

[2] A. Wibowo and B. Susanto, "Pengembangan Sistem Informasi Website KPU Daerah Istimewa Yogyakarta," J. Tek. Inform. dan Sist. Inf, vol. 2, p. 231-243, 2016.

[3] J. A. O'Brien and G. M. Marakas, Introduction to Information Sistem, New York: The Mc-Graw-Hill Companies, 2007.

[4] L. Fernando, N. Safriadi and R. D. Nyoto, "Rancang Bangun Sistem Informasi Konferensi Nasional Aptikom Provinsi Kalimantan Barat Berbasis Web," Jurnal Sistem dan Teknologi Informasi (Justin), vol. 6, no. 3, pp. 111-115, 2018.

[5] M. Z. Lestari and N. O. Syamsiah, "Sistem Informasi Piutang pada Unit Pengelolaan Keuangan Desa (UPKD) Model Desa Prima Kecamatan Sungai Pinyuh Kabupaten Mempawah," Jurnal Edukasi dan Penelitian Informatika (Jepin), vol. 3, no. 2, pp. 142 151, 2017.

[6] R. Susanto and A. D. Andriana, "PERBANDINGAN MODEL WATERFALL DAN PROTOTYPING UNTUK PENGEMBANGAN SISTEM INFORMASI," Majalah Ilmiah UNIKOM, vol. 14, no. 1, pp. 41-46, 2016.

[7] I. Sommerville, Software Engineering 9th Edition, AddisonWesley, 2011.

[8] A. W. Prasetya and M. A. Z. S. Yaqin, "Common Process Extraction Pada Scalable Model Process Bisniss," pp. 484-489, 2018.
[9] M. A. Ramdhani, "Pemodelan Proses Bisnis Sistem Akademik Menggunakan Pendekatan Business Process Modelling Notation (Bpmn) (Studi Kasus Institusi Perguruan Tinggi Xyz)," Jurnal Informasi, pp. 83-93, 2015.

[10] Ladjamudin, Analisis dan Desain Sistem Informasi, Yogyakarta: Graha Ilmu, 2005.

[11] B. Bunardi, D. S. Naga and D. Arisandi, "PENGEMBANGAN APLIKASI E-COMMERCE PRODUK LOKAL DAN DATA KEPENDUDUKANPADA DESA GIRITENGAH, BOROBUDUR," Computatio: Journal of Computer Scienceand Information Systems, vol. 3, no. 1, pp. 77-84, 2019.

[12] R. Wahyuni and H. Irawan, "Penerapan Electronic Customer Relationship Management (E-CRM) Dalam Upaya Meningkatkan Loyalitas dan Pelayanan Terhadap Pelanggan Studi Pada Bengke Yamaha Inti Mas Motor," J u r n a l I D E A L I S, pp. 489-496, 2018.

[13] M. S. Mustaqbal, R. F. Firdaus and H. Rahmadi, "PENGUJIAN APLIKASI MENGGUNAKAN BLACK BOX TESTING BOUNDARY VALUE ANALYSIS(Studi Kasus : Aplikasi Prediksi Kelulusan SNMPTN)," Jurnal Ilmiah Teknologi Informasi Terapan, vol. 1, no. 3, pp. 31-36, 2015.

[14] F. Melky, Rancang Bangun Aplikasi Virtual Reality Laboratorium Fakultas Teknik Universitas Tanjungpura, Pontianak: Skripsi, 2015

[15] F. H. Y. Yudhanto, H. Nugroho and A. H. Suryadi, "Aplikasi Pengelolaan Sistem Informasi Dinas Kesehatan Kabupaten Bandung," e-Proceeding of Applied Science, vol. 4, no. 3, pp. 1621-1629, 2018

[16] Maryuliana, I. M. I. Subroto and S. F. C. Haviana, "Sistem Informasi Angket Pengukuran Skala Kebutuhan Materi Pembelajaran Tambahan Sebagai Pendukung Pengambilan Keputusan Di Sekolah Menengah Atas Menggunakan Skala Likert," Jurnal Transistor Elektro dan Informatika (TRANSISTOR EI), vol. 1, no. 2, pp. 1-12, 2016. 